\title{
The Effect of Ethnic Conflict and Political Instability on Import Demand:
}

\section{Evidence from Turkey}

\author{
Mina Goesjenova \\ Research Advisor: Dr. Thomas Ziesemer
}

The unrest in the city center of Istanbul during the late Spring of 2013 is just one of many in the long list of instability and conflict, events responsible for a presumably underestimated amount of lives during the second half of the 2oth century. This paper focuses on the effects on imports of these occurrences. Imports are not only a way to satisfy domestic demand; they also function as an important gate to increased economic growth via importation of more advanced technology. The analysis advances the existing economic literature that incorporates institutional variables into the analysis in two distinct ways. First, internal instability has been the focus, in contrast to previous work that tried to explain changes to macroeconomic variables due to international conflict. Second, the analysis takes into account the endogeneity problem by using the VECM framework. Civil violence, that is, political instability, and ethnic conflict are found to have a positive effect on GDP per capita and import demand per capita. The nature of, and relationship between, civil violence and ethnic conflict in Turkey is pivotal in describing the influence of different macroeconomic variables on the rest of the economy. The VECM framework employed presents another intriguing result which is a characteristic embedded in Turkish ethnic history: there is evidence that ethnic conflict is not significantly endogenous to the economic environment. If the Kurdish problem is indeed the first item on the list that inhibits full-edged Turkish acceptance in the economies and politics of the West, the way to achieve ameliorated relationships between the two ethnicities is mostly through political negotiations, probably via international mediation as the ethnic strife has centuries-old roots. 


\section{Introduction}

"[M]ore than 40 percent of hotel reservations have been postponed or cancelled amid the latest social unrest and police reactions, mainly in Istanbul..."

Hürriyet Daily News, June 05, 2013'

Taksim Square in Istanbul was the epicentre of a sequence of violent clashes between protesters and military forces during the late Spring of 2013. Initially, the protesters were in opposition against the construction of a shopping area on the parcel of land where Gezi Park is currently located. ${ }^{2}$ The discontent soon spread to other subjects such as freedom of speech, freedom of the press, and the government's intrusion on Turkey's celebrated tradition of secularism. This was not the first time Taksim Square was the witness of unrest and instability; around 40 leftists were killed during the Labour Day celebrations in 1977 by yet unidentified, but allegedly right-wing extremists, during what is now known as the Taksim Square massacre, in 2010 a Kurdish suicide bomber left 32 people injured. These occurrences are just three in the long list of instability that has tainted the memories of the Turkish citizens and is responsible for a presumably underestimated amount of lives during the second half of the 2oth century. Although political instability underlie the former two occurrences, the main source of Turkish unrest, both in terms of intensity and frequency, has been the ethnic conflict between the Turks and the Turkish Kurds, as embodied in the latter example. Next to these challenges in its social sphere, Turkey faced the test of a liberalisation of its economy in 1980, when it abandoned its importsubstitution policy it had pursued for decades, following the stabilisation measures promoted by the International Monetary Fund. The uncompromising economic crisis near the end of the 1970s, which developed due to mismanagement of the economy and the ensuing large balance of payment deficits, put an end to the importance placed by the government on restricting imports, formerly regarded as a way of developing Turkey's own industrial sector. The IMF stabilization package has indeed been primarily concerned with the implementation of measures which eventually, though they are not explicitly aimed at doing so, encourage exports; this reform agenda is habitually called the Washington Consensus. However, for developing countries, the importance of imports should not be neglected; the Solow model with labour-augmenting technology illustrates this process:

1 http://www.hurriyetdailynews.com/protests-hit-tourism-but-create-new-tourists.aspx?pagelD=238\&n $I D=48223 \&$ NewsCat ID $=349$

2 As of June $28,2013$. 


$$
Y(t)=F(K(t), A(t) L(t))
$$

where $\mathrm{Y}$ is output, $\mathrm{K}$ is capital, $\mathrm{A}$ is technology, and $\mathrm{L}$ is labour. In steady state, output per worker grows at the growth rate of technology, $\theta$. Then, for developing countries, and for Turkey in this particular case, imports play a significant role in their efforts to catch up with the West, for when they set on a path of full-edged liberalisation of the economy, the nations get access to intermediate and capital goods which can be produced more efficiently (and thus for a lower price) abroad. The European Union (EU), Turkey's main trading partner, has been primarily exporting machinery and transport equipment to Turkey. Imports are thus not only a way to satisfy domestic demand; they also function as an important gate to increased economic growth via importation of more advanced technology. The excerpt from Hürriyet Daily News illustrates the macroeconomic effects of unrest and conflict. Following the previous narrative, the question naturally arises; what are the long-term consequences of conflict on the volume of Turkish import demand? This question is the topic of this study, which takes a different approach from previous research by emphasising the effect on import volumes rather than bilateral trade patterns, given the underlying reasoning and motivation of the research question. The complication of endogeneity impedes a priori predictions about the possible relationship. For it is not only that unrest can harm economic conditions, economic conditions can be the cause of the emergence of dissatisfaction and physical assaults or war. However, even in the absence of endogeneity it would be troublesome to form expectations; the effect of unrest and instability on import demand can be either positive or negative. Nitsch and Schumacher (2004) identify three main channel through which any type of violence or insecurity might hinder international trade. First, insecurity can cause people to shift their production and consumption patterns, which will eventually change (international) trade patterns. This effect can work both ways: a reduction in domestic production capacity would, at least temporarily, drive import demand. As a more direct effect, international producers may be unwilling to trade with an unstable nation due to increased risk of economic losses. Second, increased risk often leads to increased security measures, which can also inhibit either only the ease of trading, or trade entirely. Lastly, the traded goods face the direct risk of being destructed. On the whole, the total effect is thus ambiguous, particularly because eruptions of violence, such as terrorist acts, mainly have local implications. In addition, given the constant presence of insecurity and violence in Turkey, although the intensities varied greatly, the losses encountered in the trade sector could, in theory, be insurable. It is thus up to empirical analysis to provide an indication about the relationship of political violence and ethnic conflict with respect to import demand in Turkey. This paper 
is organised as follows. Section 2 provides an overview of the existing literature and the methods employed in investigating the institutional effects on macroeconomic variables. Section 3 covers the specific case of Turkish instability and unrest and the nation's recent economic (policy) history. Next, section 4 presents the data and the methodology, whilst section 5 introduces and elaborates on the empirical results using the vector error correction model (VECM) and impulse response analysis. Naturally, section 6 brings the paper to a close by presenting the conclusions and thoughts for future research.

\section{Literature review}

This section provides an overview of a selection of influential literature pertaining to the effects of political instability and ethnic conflict on general economic performance (subsection 2.1) and, in particular, import demand or trade (subsection 2.2). Although the first subsection is rather brief in view of the amount of existing literature, it is interesting for two reasons; first, in its own right, it is essential to know the economic costs of conflict, and, second, the literature regarding this topic is more mature than the existing literature regarding the relationship between internal conflict and trade and/or import demand, and will thus provide a convenient overview of methods available for this field of study.

\subsection{Political and ethnic unrest and the effect on economic performance}

The relationship between political instability and social conflict with respect to economic growth has gained popularity in the academic field over the years. A particularly interesting and pivotal aspect of research has been the direction of causality between the institutional factors and the economic situation. Although Barro and Lee (1994) are more concerned with explaining economic growth than understanding its relationship with political instability, the authors recognise the importance of including institutional factors. The analysis involves the generalised least squares (GLS) technique (in order to correct for serial correlation) and the use of the lagged values of potentially endogenous variables as instrumental variables. Barro and Lee define instability in terms of the average number of revolutions per year occurring in the preceding five years as an instrument for domestic political stability. Nevertheless, the resulting reduction in the sample size due to missing data in the beginning of the sample produces a preference for the use of a revolution variable that is the average number of successful and unsuccessful revolutions per year over the full sample. Both of these proxies for political conflict have 
a significantly negative effect on economic growth. This method of GLS relies on the authors' assumption of random individual effects; however, as Caselli, Esquivel, and Lefort (1996) show, the use of a lagged dependent variable necessarily makes this assumption invalid and the coefficient estimates inconsistent due to correlated country-effects. In their article which emphasises the relationship between economic growth and political instability to a greater degree than Barro and Lee, Alesina, Özler, Roubini, and Swagel (1996) adopt a different approach in order to account for the simultaneity problem by using a simultaneous equations model (SEM) of the following system of two relations for political instability and economic growth:

$$
\begin{aligned}
\operatorname{prob}(\text { govchange })= & \varphi\left(\gamma_{c 1} \text { growth }+\alpha_{c 1} \text { exadje }_{-1}+\alpha_{c 2} \text { govchange }_{-1}+\beta_{c 0}\right. \\
& +\beta_{c 1} \text { growth }_{-1}+\beta_{c 2} \text { worldgrowth }_{-1}+\beta_{c 3} \text { latin } \\
& \left.+\beta_{c 4} \text { africa }\right) \\
\text { growth }=\gamma_{\gamma} \text { govchange } & +\alpha_{\gamma 1} \text { educ }+\beta_{c 0}+\beta_{\gamma 1} \text { growth }_{-1}+\beta_{\gamma 2} \text { worldgrowth }_{-1} \\
& +\beta_{\gamma 3} \text { latin } \\
& +\beta_{\gamma 4} \text { africa }
\end{aligned}
$$

where lagged worldgrowth is used to control for the relative performance of the country, and latin and africa are used to control for region-specific factors. The lagged variable exadj is used to account for incipient unrest, as it reflects changes in executive powers in preceding years. Using data covering 113 countries over a sample period from 1950 through 1982 , they define political instability as the imminent probability of government collapse. Alesina et al. (1996) find that political instability reduces growth. The effect of economic performance on the probability of government change is less clear, and depends on the degree of democracy and the type of turnover. This latter effect of the economy is only strong for coup d'états. As the authors themselves point out, however, the outcomes are solely based on major government changes, and thus disregard the frequent coalition reshuffling that occurred in Turkey prior to the military coup of 1980; these minor changes are nevertheless indicative of underlying unrest. Additionally, Deaton and Miller (1995) describe a methodological error in the approach of Alesina et al.; the latter exclude exogenous variables based on their insignificance in the reduced form rather than the correct approach, which entails the exclusion of exogenous variables from structural equations a priori. Vector auto regression (VAR) modelling has the advantage over the previous two methods of not requiring the often ad hoc decision about which variables 
are exogenous, as the VAR technique assumes all variables are endogenous. Araz-Takay, Arin, and Omay (2009) implement the VAR technique for Turkey using quarterly data from 1987 to 2004. Their study contributes to the existing literature by incorporating the possibility of an endogenous and non-linear relationship between political conflict and economic activity with a specification of a smooth transition vector auto-regression model. ${ }^{3}$ The authors conclude that there exists an endogenous, non-linear relationship between conflict and economic performance; the causation from economic activity towards terrorism only holds during recessionary periods. Policy-makers should be more careful during expansionary periods, however, as terror shocks seem to have larger-inmagnitude effects on the economy.

\subsection{Political and ethnic unrest and the effect on trade}

The existing trade literature can be broadly partitioned into two types of investigations. The first strand seeks to explain the volume of trade for individual countries by studying factors that could promote or inhibit import or export demand. The second type of literature is more concerned with trade patterns and endeavours to decipher which factors account for the differences in existing trade intensity between pairs of nations, often by making use of the gravity model of trade first promoted by Tinbergen (1963). Significantly more effort has been put into understanding the consequences of international or bilateral conflict on trade patterns than the effect of internal instability on a nation's trade volume. Consequently, all of the literature discussed next implement the gravity model of trade in the analysis.

Blomberg and Hess (2006) identify two channels through which conflict affects economies: the domestic channel and the trade channel. The domestic channel concerns the allocation of factors; if the government spends a larger amount for military purposes, this will likely crowd out investment and/or consumption. Naturally, a decline in investment now will lead to lower economic growth in the future. Any type of conflict, be it external or internal, affects the economy via the trade channel by imposing a distorting tariff on trade, inhibiting free trade and thus leading to a fall in economic activity (Blomberg \& Hess, 2006). It is essential to recognise that the endogeneity problem continues to be a possibility, for imports can come at times of shortages and exports can function as a means to do away with domestic surpluses in production (Csaki \& Lerman, 2001). Blomberg and Hess pursue the second channel in their investigation to quantify the effect

3 Araz-Takay et al. (2009) define political instability using a terror index that is the natural log of $(1+$ number of human causalities + number of people injured + number of terrorist attacks). 
of all types of conflict on trade; the types of conflict included are terrorism, external war, revolutions, and inter-ethnic fighting, where revolutions proxy political instability. ${ }^{4}$ The authors use a panel data set covering 177 countries from 1968 to 1999, and their regression results include country- and time-fixed effects. They find a robust relationship between conflict and trade; for the purposes of this paper only the effects of terrorism, inter-ethnic fighting, and revolutions will be mentioned. All three types of conflict experienced by one of the two countries significantly reduce bilateral trade; terrorism reduces bilateral trade by 4 percentage points and inter-ethnic fighting reduces trade by 12 percentage points. If both trading countries experience revolutions this will reduce their bilateral trade by 40 percentage points. Blomberg and Hess account for endogeneity by using IVs, but this does not alter the main thrust of the article. In the same vain, Nitsch and Schumacher (2004) use an augmented gravity model with several measures of both internal and external conflict and violence, and find that an increase in any type of domestic violence greatly reduces the volume of bilateral trade flows. A significant neglect in this latter article is the absence of any consideration of endogeneity; the authors solely employ the ordinary least squares (OLS) technique with year effects. Another branch of research has endeavoured to distinguish whether there are different effects depending on whether the conflict takes place in the importing country or the exporting country. Srivastava and Green (1986) make this distinction and define political conflict as the irregular transfer of power. They find that low levels of instability in the exporting nation are associated with higher trade intensities. The same result does not hold in their analysis for instability in the importing nation: the coefficients are insignificant in the majority of the cases. Similar results were found by Eckstein and Tsiddon (2004), who examined the short-run effects of terrorism on the macroeconomy in Israel using the VAR method; the impact on exports was much more volatile than the impact on, for example, non-durable consumption. However, Eckstein and Tsiddon disregard the effects of conflict on import demand. Neyapti, Taskin, and Üngör (2007) do consider all trade, and find a positive effect of political security on Turkish export demand and, in contrast to Srivastava and Green (1986), also on import demand. However, endogeneity is not inspected.

The current study will contribute to this branch of literature, which reports conflicting results, in three different ways. First, it deviates from the aforementioned articles as it endeavours to explain fluctuations in Turkish import demand rather than bilateral trade

4 Blomberg and Hess (2006) also employ a synthetic measure of violence (TERIF) in order to analyse the aggregate effect of violence on trade. 
volumes, as the point of interest is not the explanation of trade patterns, but the allocation decision of Turkish citizens in terms of preferences and their purchasing abilities. Second, following Araz-Takay et al. (2009) and Eckstein and Tsiddon (2004), this paper will make use of the VAR technique. Lastly, internal conflict, which is characteristic of Turkey politics of the twentieth and current century, is emphasised and explored using a novel data set for Turkey, with institutional variables which expand their assessment of the stability beyond eruptions of violence, endeavouring to capture the general sense of unrest.

\section{Turkey's history of social and political unrest and trade liberalization}

Turkey's experience after the Second World War is one marked with trial-and-error economic policy measures, recurring large balance of payments deficits and economic downturns, soaring inflation, and political and social unrest that aggravated the aforementioned hardships. Nevertheless, the military coup of 1980 recorded a series of stabilisation programs, initiated under the guidance of the IMF and the Organization of Economic Cooperation and Development (OECD). The experience in the years that followed was one that outperformed the failing economies of Latin America, which were hit by similar factors in the early 1980 s. As Turkey has probed its way through to the 21st century, the economic problems have decreased in severity. Politically and socially, however, there is far more to be achieved, as can be seen by the 2013 protests in Turkey. This section is designed to show that such upheaval is part of a larger history of periodic unrest, and is organized as follows; it first covers the past of instability and unrest in subsection 3.1, and subsequently gives a brief summary of the Turkish history of economic performance and trade policies in subsection 3.2.

\subsection{Three main categories of violent organizations}

Turkey has a long history of instability in its political and social environment, the most noted exemplar being the Kurdish question. Rodoplu, Arnold, and Ersoy (2003) argue that the problems have roots in the turbulent 1960 s and 1970s. The coup of 1960 was the first one in a series of three. The import-substitution policies, which were already in place before the coup, were continued to be implemented throughout the two decades that followed, and Turkey fared well through the 1960s with growth rates as high as 11.2 per cent. As the decade progressed, however, Turkey tumbled into a clash with the emerging 
left-wing Workers Party of Turkey. The situation deteriorated with the use of violence, but the coup of 1971 did little to stop the chaos that was tormenting the country, and as the 1970 wore on, the oil crises aggravated the existing circumstances. The latter half of the 1970 s presented Turkey with problems on all possible fronts. The economy was in a state of stagflation, social upheaval was omnipresent, and law and order were nearly non-extant. The Turkish National Security Council has recorded an estimate of 43,000 terrorist attacks with an average of 28 deaths for the time period between 1978 and 1982 (Rodoplu et al., 2003). Aricanli and Rodrik (1990) even describe the occurring circumstances between 1976 and 1980 as a situation of anarchy. During the 1970s, three main categories of violenceprone organizations emerged from both left- and right-wing extremes, and they will be described seriatim hereafter.

\subsubsection{Kurdisch separatist organizations}

The Kurdish question is one of the greatest obstacles to the consolidation of democracy in Turkey (Ergil, 2000). Until this date, it has been a significant impediment in Turkish attempts to integrate and become accepted by the European community and the West. This conflict has its origins rooted centuries ago, but the strengthening of the Kurdish cultural identity in the 2oth century, through, amongst others, the spread of democratization and human rights, has ignited a larger willingness of the Kurds to combat Turkish oppression. The turbulence of the 1970s provoked the formation of the Partiya Karekayen Kurdistan (PKK), the Kurdistan Worker's Party, in 1978. The PKK has been the most successful in promoting the Kurdish cause, which was the establishment of a Kurdish state in the south-eastern part of the country, the region with the highest concentration of Kurds. The Kurdish question, more than anything, seems to be centred around the issue of ethnicity. Rodoplu et al. (2003) identify four causes that have led to the strengthening of the Kurdish organisation; economic disparity between the underdeveloped region in south-east of Turkey and the more developed western areas, the emergence of the Kurdish cultural identity, the periodic support from other countries, and establishment of a de facto Kurdish state in the north of Iraq as a consequence of the First Gulf War.

The military coup of 1980 soon put an end to Kurdish and other resistance by using harsh measures, but the return to civilian rule in 1983 meant the return of violence. The PKK guerillas were able to maintain the upper hand over Turkish security forces during the 1980s. In 1995, the Turkish army was adequately equipped and trained in order to gain military superiority. Nevertheless, in the years that followed clashes between the two forces have occurred periodically, the most recent considerable example being the 
2011-2012 Kurdish protests. ${ }^{5}$ Besides the general air of hostility between the Kurds and the Turks, there have thus been numerous recorded Kurdish violence acts, such as shootings, (suicide) bombings, and arson, all of which had injured victims, and in many cases resulted in fatalities. ${ }^{6}$ It has been estimated that around 35,000 citizens have been the victims of separatist violence in the years between 1984 and 2000 (Rodoplu et al., 2003). Ergil (2000) reports that in addition to these murders, there have been an additional 10,000 purported 'mystery killings', committed by unknown perpetrators in order to fuel Kurdish anxiety by eliminating Kurdish politicians and other elites. The Kurdish separatist organisation appear to be the most difficult to defeat for the Turkish military forces, which is in congruence with the finding of Akyuz and Armstrong (2011), who found that, while controlling for the influence of poverty and residential mobility, ethnic heterogeneity was predictive of terrorism in Turkey.

\subsubsection{Radical Islamic organisations}

The main goal of the radical Islamic organisations is to establish an Islamic sharia-based state, which would replace secularism. The most significant of these organizations is the Turkish Hizbullah.7 Although it is still rather unclear when it was established, the Turkish Hizbullah became known after the Iranian Islamist Revolution during the beginning of the 1980s. During the early 1990s, the Hizbullah and the PKK had been involved in a conflict with each other, which took a toll of more than 700 human lives (Rodoplu et al., 2003).

\subsubsection{Leftist (Marxist) organisations}

The leftist organisation have endeavoured to establish an order in Turkey which would follow the ideas of communism, and thus have promoted the creation of a state in which a classless society would emerge due to wealth distribution according to Marxist ideas. These organisations have been particularly successful during the student protests of the 1970s, but have decreased in popularity and power due to internal organisation problems, which led to division of the larger organisations into several weak, smaller ones.

5 These protests have resulted in the death of 110 Turkish soldiers and 427 PKK guerillas.

6 For a complete and detailed list of Kurdish violent actions for the years 1986-2001, see Rodoplu et al. (2003).

7 The Turkish Hizbullah is not thought to have any connection with the Lebanese Hizbullah. 


\subsection{The path to trade liberalisation}

Turkey entered the 1970 s with high growth rates. The combination of the import substitution policy with the remittances of more than half a million migrant workers who were working in, for example, the Netherlands or West Germany, meant that the fixed exchange rate could be maintained without much difficulty. In 1974, when the first oil crisis was still harming the economies of Western countries, the Turkish government continued pursuing its high-growth policy. The consequences of this would be far-reaching: import demand increased whilst the ailing economies of the West reduced their export demand as well as their labour demand. ${ }^{8}$ It was not until 1976 that Turkey's economy collapsed. The external debt was growing at a fast rate, and the government realised that it was time for change. In January 1980, under the guidance of the IMF, the Turkish economic policy was transformed completely: an outward-looking approach was adopted. The fixed exchange rate was gradually turned into a floating one, and whilst the domestic import demand suffered from the austerity measures of the government, the export sector was experiencing a large increase due to the export drive in the form of subsidies. In 1984 , the Import Program (IP) became effective. Until the economic liberalisation, import demand was restricted with quotas, and unless a certain good was mentioned on an official import list, it was considered prohibited. The IP constituted the implementation of a so-called negative list, which, contrary to the preceding list, contained information about goods which were not allowed to be imported, thus substantially reducing the role of import quotas. Aricanli and Rodrik (1990) argue, however, that the IP's effectiveness was reduced because some import quotas were adjusted upward and additional import levies were imposed. Levinsohn (1993) shows that, in all but two industries, protection has been reduced. 9 In the years that followed the liberalisation of its economy, Turkey has been importing capital-intensive goods from Western countries and exporting primarily textiles, clothing, steel, and iron. In 2012, the European Union was Turkey's largest trading partner (Commission, 2013). In that year, 38.1 per cent of EU exports accounted for Turkish import demand, whilst 46.2 per cent of Turkish exports was destined to the market of the European Union members.

8 A reduction in remittances meant that there were considerably less remittances to make the current fixed exchange rate a sustainable one.

9 The inclusion of an IP dummy variable in the analysis in section 5 supports the conflicting results of Aricanli and Rodrik (1990) and Levinsohn (1993): it always proves to be insignificant. It has thus been decided to exclude it from the regressions. 


\section{$4 \quad$ Data and methodology}

\subsection{Data}

The economic and demographic data has been extracted from the OECD iLibrary, and covers the following three variables: nominal and real GDP, nominal and real imports, unemployment rate, and population..$^{10}$ These have been used to construct the following natural logarithm-transformed variables: $\ln \frac{\text { Real Imports }_{t}}{\text { Population }_{t}}=\ln I M C$ and $\ln \frac{{\text { Real } G D P_{t}}_{\text {Population }_{t}}}{\text { Pon }_{\text {on }}} \ln$ GPC. The values for nominal and real GDP and imports were employed to construct an imports deflator and a GDP deflator, which function as inputs for the relative price ratio of imports to domestic prices." In addition, the annual total EU15 real GDP was used as an exogenous variables as a means to proxy the income component in the export demand function..$^{2}$ Other exogenous variables included a dummy for the 1999 earthquake that had a magnitude of 7:4,13 and a dummy for the Turkey's accession to the World Trade Organisation (WTO) in 1995. Turkey has been a member of the General Agreement on Tariffs and Trade (GATT) since 1951; however, the GATT had no institutional foundation. The WTO was established as a permanent international institution that would replace rather than function as an extension of the GATT. Given the different nature of the WTO, this study makes the assumption that WTO is an exogenously binding institution. The vital data for this study are the measures of political instability and ethnic conflict, which were gathered from the Integrated Network for Societal Conflict Research (INSCR) database of the Center of Systemic Peace (CSP). ${ }^{14}$ The dataset used was the Major Episodes of Political Violence (MEPV) and Conflict Regions. In this dataset, episodes of violence are coded according to their time span and magnitude. As a result, there are seven categories of violent conflict: : international violence (IV), international war (IW), international independence war

10 http://www.oecd-ilibrary.org/statistics

11 The base year for the real values of imports and GDP is 2000. The relative price index was calculated as follows:
RELPRICE $_{t}=\frac{P I_{t}}{P G D P_{t}}$
(4), where
$P I_{t}=\frac{\text { NOMINAL IMPORTS }_{t}}{\text { REALIMPORTS }_{t}}$
(5), and
$P G D P_{t}=\frac{\text { NOMINAL GDP }}{\text { REAL GDP }}$
(6)

12 The EU15 contains the main trading partners of Turkey over the last decades and has the advantage of data availability over the entire sample size.

13 Source: http://earthquake.usgs.gov/earthquakes/eqarchives/year/1999/1999 08 17.php

14 http://www.systemicpeace.org/inscr/inscr.htm 
(IN), civil violence (CV), civil war (CW), ethnic violence (EV), and ethnic war (EW). For this study's purposes, only the latter four categories are important for they represent internal conflict. Each episode of violence is judged to have spanned a certain amount of years ("inclusive years") and have a general "magnitude of societal-systemic impact", which is measured along an eleven-point scale (o-10). The magnitude scores are considered consistent and comparable across episodes and categories; in this sense, these scores approximate a ratio scale. The categories used were thus civil violence, civil war, ethnic violence, and ethnic war, and as the differences are rather subtle, they require some further elaboration. An episode of civil war or violence involves rival political groups, whereas ethnic conflict concerns the state agent and a distinct ethnic group (Marshall, 2012). The CSP further distinguishes between an episode of war and an episode of violence. However, these categories can be seen as somewhat arbitrary, violence is defined as "the use of instrumental violence without necessarily exclusive goals", whereas war is "violence between distinct, exclusive groups with the intent to impose a unilateral result to the contention" (Marshall, 2012). Given the intricacy in deciding whether it concerns an episode of violence or war, in addition to multicollinearity complications, it has been decided to compile these measures into a single variable indicating the severity of the ethnic conflict. Figure 1 depicts the magnitude scores for Turkey from 1970 to 2008. As can be seen, there are no episodes of civil war. The highest magnitude score is for ethnic war for the years following the return of civilian rule (1983) after the military coup of 1980; during this period, the Kurdish separatists were able to keep ahead of the Turkish military. The civil violence scores prevail around the end of 1970s, the turbulent times leading up to the coup.

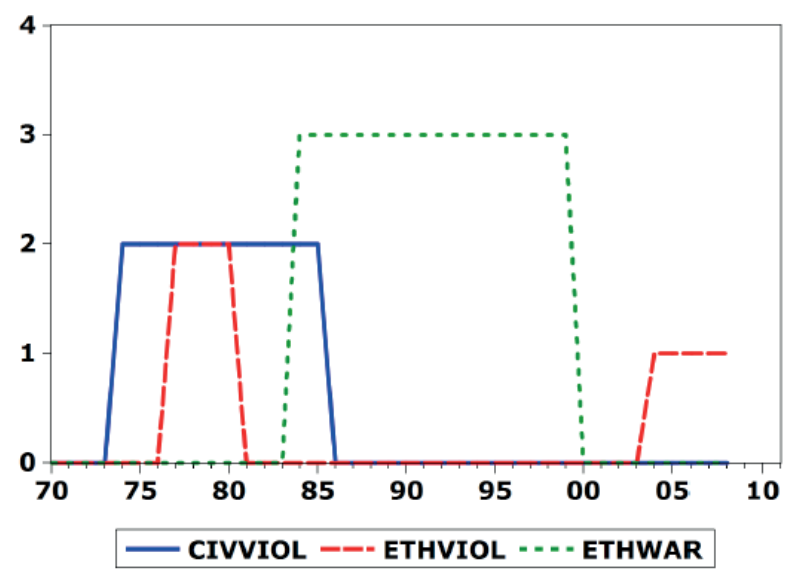

Figure 1: Magnitude scores for Turkey from the Major Episodes of Political Violence dataset: 1970-2008. 


\subsection{Methodology}

For the basic methodology the VAR framework will be employed following Araz-Takay et al. (2009) and Eckstein and Tsiddon (2004). The main object of this study is a VEC model estimation of conceivably relevant endogenous variables: the natural logarithm of imports per capita, In(IMC), the natural logarithm of GDP per capita, In(GDPC), the natural logarithm of relative prices, In(RELPRICE), the unemployment rate, UR, the magnitude scores for ethnic conflict and civil violence, eth, and civviol, and the following exogenous variables: a dummy for membership of the World Trade Organisation, WTO, a dummy for the earthquake of 1999, earth, and the natural logarithm of the total GDP of the EU 15, EUGDPTOT. The macroeconomic endogenous variables have been chosen following Houthakker and Magee (1969). The empirical analysis proceeds in the following four steps. The first step involves a stationarity test. The standard procedure of the augmented Dickey-Fuller test with a constant (and an optional time-trend) indicated that $\ln (G D P C)$, UR, eth, civviol, and EUGDPTOT are I(1) processes. The reason for the rejection of the hypothesis of a unit root for $\ln (I M C)$ might be that the inclusion of the deterministic trend happens to fit this particular part of the $\ln (I M C)$ process well. Fortunately, variables that are I(O) or I(1) can both be included in VEC models, so these results do not inhibit the analysis. The exogenous variable EUGDPTOT was included in the model in its first-difference form, $\triangle E U G D P T O T$. Second, the Akaike Information Criterion, the Schwarz Critereon, and the Hannan-Quinn Information Criterion were used to determine the appropriate lag length. Although all criteria initially recommended a model with lag length (3), this model proved to be unstable, and consequently all criteria indicated an optimal lag length of (2) $)^{15}$ This corresponds with a lag length of (1) in the VEC model. Third, stability was established for the VAR estimation, which included a linear deterministic trend, using the AR roots table. ${ }^{16}$ The last step, which involves the Johansen co-integration test is discussed in the next section. The Johansen co-integration test critical values do not take into consideration the inclusion of exogenous variables; this study assumes that the implications of this are not severe and utilises the values reported in the tests as though no exogenous variables have been used.

15 See Appendix D in Goesjenova (2013).

16 See Appendix C in Goesjenova (2013) 


\section{Empirical results}

\subsection{Johansen co-integration test and VECM estimation}

The Johansen co-integration test indicated divergent results regarding the amount of co-integrating equations (CEs), depending on whether the trace test or the maximum eigenvalue was used, and which critical value was employed. At the standard critical value of 0.05 , the trace test indicated three CEs, whilst the maximum-eigenvalue test indicated two. For the results of these tests, see Table 2 in Goesjenova (2013). Given that the maximum-eigenvalue test rejected the hypothesis of three co-integrating relationships at a very small margin, it has been decided to follow the result of the trace test.

The three co-integrating equations are addressed in Table 3. The preferred model specification was achieved through the following procedure. Co-integration restrictions were applied to adjustment coefficients in succession; a coefficient was restricted to $\mathrm{o}$ if it had the lowest statistical significance in the adjustment coefficients vector. This procedure was terminated and an optimal specification was selected when the LR test for binding restrictions with $r=3$ indicated that imposing another restriction resulted in a lower probability of the $\chi^{2}(3)$ statistic. The restrictions are as follows: $A(2 ; 1)=0 ; A(5 ; 2)$ $=O$ and $A(5 ; 3)=O$, where $A(2,1)$ is the adjustment coefficient for $C E(1)$ of the estimated equation for $\triangle \ln (G D P C) ; A(5,2)$ and $A(5,3)$ are adjustment coefficients of the estimated equation for $\Delta$ eth for co-integrating equation (2) and (3), respectively. ${ }^{17}$

Running counter to Okun's Law, although admittedly the "law" is a rough rule of thumb, $U R$ has a positive ceteris paribus long-run effect on $\operatorname{In}(G D P C)$. The VECM predicts that as the unemployment rate rises one percentage point, output per capita will grow approximately 6.o per cent. Similarly, the unemployment rate is estimated to positively influence imports per capita by 3.1 per cent for an increase in UR of one percentage point. Rodoplu et al. (2003) provide a possible explanation for this counter-intuitive implication from the VECM. During the 1960 s, and the two decades that followed, Turkey was experiencing a high growth in its urban population. Rodoplu et al. argue that the urban labour demand could not match the vast increases in urban population, and although there were large gains made in labour productivity over time as the manufacturing sector was taking over the role of agriculture

$17 \quad B(1 ; 1)=1 ; B(1 ; 2)=0 ; B(1 ; 3)=0 ; B(2 ; 1)=0 ; B(2 ; 2)=1 ; B(2 ; 3)=0 ; B(3 ; 1)=0 ; B(3 ; 2)=0$; $B(3 ; 3)=1$ were additional restrictions required by the statistical program (EViews) to achieve the intended model specification. Coefficient $B(x, y)$ is the coefficient of variable $y$ of co-integrating equation $\mathrm{x}$, where $\ln (I M N C)$ is variable $1, \ln (G D P C)$ is variable 2 , and $\ln (R E L P R I C E)$ is variable 3. 
as the leading sector, the unemployment rate was increasing despite this progress. The relationship found between UR and $\ln (I M C)$ is likewise supported by the previous argument, for part of the increased consumer demand is satisfied by foreign producers. The coefficient of UR in $C E(3)$ is negative and does not tally with UR effects in $\operatorname{CE}(2)$ and $C E(3)$; however, the statistical significance of this effect is very low.

The signs of the coefficients of the institutional variables run counter to the effects found by the literature discussed in section 2. Civil violence and ethnic unrest are both expected to increase $\ln (G D P C)$ by 12.8 and 23.9 per cent, respectively. These effects do not correspond with the negative relationships established by, for example, Alesina et al. (1996) and Araz-Takay et al. (2009). Similarly, the positive influence of civviol and eth on $\ln (I M C)$ do not coincide with the negative effects found by Blomberg and Hess (2006) and Nitsch and Schumacher (2004). The answer to this empirical riddle lies in the nature of the episodes of political and ethnic instability that Turkey has been experiencing. When interpreting the meaning of the coefficients in the VECM, it is natural to interpret them ceteris paribus. However, in Turkey's case, it is unlikely that one can comment on the effect of a change in eth in the CEs while keeping other variables, in particular civviol, constant. This can be seen in simple regressions of civviol on eth, and of eth on civviol, using a constant, a time trend, and allowing for an AR(r) process. These tests reveal that eth is a good predictor of civviol, although this is not the case for the regression of eth on civviol. The preferred specification for the former relation is as follows (the numbers below the coefficients are the $p$-values):

civviol $=\underset{0.000}{2.675}-\underset{0.028}{0.168} \operatorname{eth}+\underset{0.005}{0.493 A R(1)}-\underset{0.307}{0.084 A R(4)}-\underset{0.000}{0.084 t}$

Equation 8 shows that there is a negative relationship between ethnic conflict and civil violence; this implies that when considering the long-term effect of eth in the three co-integrating relationships, it is rather implausible to hold civviol constant. Conversely, the ceteris paribus assumption does appear to hold for the effect of civviol in the three CEs; the episode of civil violence, that is, political instability, experienced in Turkey, was, as described in section 3 , one that entailed the installation of an authoritarian military regime that was able to extend its power to all aspects of society, and, with the help of the IMF, introduced profound restructuring of the economy.

As will be explained in subsection 5.2, however, the success of this government in and of itself is disputable. Aricanli and Rodrik (1990) argue that the turnaround in economic performance in the 1980 s is particularly attributable to vast official capital inflows from abroad that were employed as a means to "buy" Turkish stability and partiality in the First 
Gulf War (Aricanli \& Rodrik, 1990). Hence, the effects on $\ln (G D P C)$ and $\operatorname{In}(I M C)$ observed are positive. The influence on In(RELPRICE) of both variables is negative; as the VECM assumes endogeneity of all the variables, the relationship in $\mathrm{CE}(3)$ can thus be interpreted both ways; a higher domestic price level can increase discontent.

VECM Estimates: Co-Integrating Equations

\begin{tabular}{|c|c|c|c|}
\hline \multicolumn{4}{|c|}{$\begin{array}{l}\text { Sample (adjusted): } 1976 \text { - } 2007 \\
\text { Included observations: } 32 \text { after adjustments }\end{array}$} \\
\hline $\begin{array}{l}\text { Cointegrating } \\
(C E) \Longrightarrow\end{array}$ & $C E(1) \downarrow$ & $C E(2) \downarrow$ & $C E(3) \downarrow$ \\
\hline $\ln (I M C)_{t-1}$ & 1 & 0 & 0 \\
\hline $\ln (G D P C)_{t-1}$ & 0 & 1 & 0 \\
\hline $\ln (R E L P R I C E)_{t-1}$ & 0 & 0 & 1 \\
\hline \multirow[t]{2}{*}{$U R_{t-1}$} & -0.031 & -0.060 & 0.002 \\
\hline & [-1.888] & {$[-11.667]$} & [0.145] \\
\hline \multirow[t]{2}{*}{$e t h_{t-1}$} & -0.166 & -0.128 & 0.113 \\
\hline & {$[-7.854]$} & {$[-19.527]$} & [6.286] \\
\hline \multirow[t]{2}{*}{ civviol $_{t-1}$} & -0.367 & -0.239 & 0.126 \\
\hline & {$[-8.594]$} & {$[-18.123]$} & {$[3.469]$} \\
\hline \multirow[t]{2}{*}{ trend $(1970)$} & -0.096 & -0.041 & 0.008 \\
\hline & {$[-17.196]$} & {$[-23.626]$} & {$[1.635]$} \\
\hline constant & 4.206 & 0.925 & -0.522 \\
\hline
\end{tabular}

The intricate interrelations between variables in a VECM prevent straightforward interpretation of estimated coefficients, particularly for the effect of eth, as explained previously. In order to better understand the working of the complete model, the next section will apply changes to eth and civviol, and employ impulse response analysis to focus on both short-run and long-run estimated effects. The complete VEC model is reported in Goesjenova (2013).

Lastly, it is worthwhile to consider the estimated effects of the included exogenous variables as reported in the set of equations above. In this discussion, emphasis is put on the effects these variables were intended to capture. The WTO dummy promotes imports by doing away with trade restrictions, and additionally has positive effect on the change in $\ln (G D P C)$ - most probably this is the effect of enhanced efficiency through comparative advantage. The earth dummy has a negative impact $\ln (G D P C)$, as expected. $\triangle E U G D P T O T$ 
has a positive effect on the change in relative prices: more demand from abroad decreases the domestic prices relative to the price level of imported goods. ${ }^{18}$

\subsection{Impulse response analysis}

Following economic theory and intuition, there exist both short-run and long-run interactions between variables, as is embodied in concepts such as overshooting and sticky variables. This section encompasses impulse responses, which are derived from the VECM and set out the impact of an exogenous conflict or instability shock on the variables in the system. The responses to an innovation in eth and civviol are shown in Figure 2 and Figure 3, respectively.

A positive and temporary innovation of one standard deviation of eth, which is around 1.353, is applied in period o. A one-time increase in ethnic conflict has a self-perpetuating effect in the long run; the effect is positive and persistent at around an increase of 0.551 in the magnitude score. This result is relatively large as it is around 35.2 per cent of the mean value of eth over the sample period. Increased conflict leads to increased media attention, and is a way of strengthening and showing the Kurdish identity. Indeed, the use of media channels such as agitpop to expand adherents is one of the reasons for the increase in Kurdish separatist groups and the emergence of the Kurdish cultural identity (Rodoplu et al., 2003). However, this unification effect works both ways; the Turks start to feel it is more pressing to keep the upper hand in this ethnic strife and thus focus less on intraethnic conficts. Civil violence has mostly surrounded Turkish discontent about the Turkish government. The impact on civviol is thus negative with a factor of 0.110 , which is around 17.9 per cent of the mean score of civil violence and tallies with the implied relation in equation 8 . For the discussion of the other responses, it is important to repeat that ethnic conflict has primarily affected the already economically backward, south-eastern regions of Turkey, where the overwhelming majority of the Turkish Kurds lives, whilst civil violence has naturally been located near the governing organs of the nation in Ankara and Istanbul. A decrease in civil violence, thus, creates an environment in which the Turkish economy, which is concentrated in the west of the country and has been primarily blooming in that part of the nation, can resume its activities. Therefore, as can be seen in Figure 2, GDP per capita increases by 2.1 per cent, the unemployment rate decreases by 0.379 percentage points, and since domestic supply is boosted, the relative prices decrease by 4.8 per cent, leading to an increase in import demand per capita of 3.9 per cent. This latter figure is

18 This can be seen as follows: a negative $\triangle E U G D P T O T$ indicates that demand at $t-1$ was higher than at $t$. Therefore, $\Delta I n$ (RELPRICE) is negative, meaning that relative prices at $t-1$ are higher than at $t$. 
in line with the long-term relationship implied by $C E(1)$ of the VECM.19 The short-run responses of all the variables to the innovation in eth are characterised by overshooting as there is a large initial effect of eth on itself. As time passes, however, the conflict lessens in severity most likely because one party prevails. An adjustment process follows during which all the endogenous variables experience ups and downs.

The 1980 military coup d'état can be considered a natural experiment during which Turkey experienced a shock of better organised and pervasive violence of the military government as the strife of the late 1970s between Turkish citizens and between the Turks and the Kurds carried on into the 1980s. A one-time innovation of one S.D., which is around 0.935, in civviol, is applied in figure 4, and is likewise self-perpetuating: in the long term it implies an increase in the magnitude score by 0.075 , or around 12.2 per cent of the sample mean. The nature of the episode of civil unrest that Turkey experienced during the late 1970 s and the early 1980 s is vital for understanding the responses of the variables to the impulse. The military coup of 1980 meant the end of the inter-ethnic war, but this was achieved through harsh measures, such as killings of opponents of the military regime in order to excite fear into the minds of the public, and, in particular, the Kurds - this explains the long-run reaction of -0.101 points of eth to the innovation. The economic variables show the following effects: GDP per capita experiences a negligible decrease of 0.05 per cent, the unemployment rate declines 0.091 percentage points, whilst relative prices increase slightly by 0.2 per cent. Despite this increase in relative prices, import demand per capita grows 0.8 per cent in the long run. ${ }^{20}$ Thus, the impulse response analysis of the effects of civviol on $\operatorname{In}(G P D C), \operatorname{In}(R E L P R I C E), \operatorname{In}(I M C)$, and UR suggest that the results of the stabilisation efforts were at most imperceptible, if not slightly negative. This corresponds to the analysis of Aricanli and Rodrik (1990), who argue that although Turkey has been praised for the turnaround in economic performance after the policies implemented by Turgut Özal in 1980, "the impact of reforms on the real economy has not been spectacular". Although the reforms were, amongst others, aimed at creating export-stimulating conditions, problems such as mismanagement and frequent revisions of policies, common to economies that have just set on a path of liberalisation, were commonplace. For example, the continuous fiddling with the allocation of export subsidies created a rent-seeking environment, and thus impeded the attainment of the intended spectacular

$19 \Delta \ln (I M C)=0.031 \Delta U R+0.166 \Delta e t h+0.367 \Delta$ civviol $=0.031^{*}-0.379+0.166^{*} 0.551+0.367^{*}-0.110 \approx 0.039$. Differences are due to rounding.

20 A similar calculation can be performed for the shock in civviol: $\Delta \ln (I M C)=0.031 \Delta U R+0.166 \Delta$ eth + $0.367 \Delta$ civviol $=0.031^{*}-0.091+0.166^{*}-0.101+0.367^{*} 0.075 \approx 0.0009$. Differences due to rounding. 
growth. In addition, the self-perpetuating effect of civil violence could likewise inhibit growth; the effect discussed for the influence of eth on $\ln (G D P C)$ is valid here too. The localisation of political unrest in the western parts of the nation is a possible additional barrier to growth. The short-run effect on $\ln (G D P C)$ reflects the conflicting assessment of Turkish growth after the liberalisation of its economy: the conclusion of these assessment depends on (the length of) the time period examined.

The growth, although small, in $\ln (I M C)$ is a probable consequence of the negligible effect on production and the inability of domestic producers to meet domestic demand after liberalisation of the import sector. Another possible, partial explanation is one that also has some explanatory power for the previous impulse response analysis involving eth: an increase in arms imports as a response to proliferating unrest. Blanton (1999) found that arms contribute to citizen repression and insecurity by making violent acts more feasible. Growing conflict requires extra-budgetary military expenses in order to restore peace, irrespective of whether the re-established order is democratic or authoritarian. The aforementioned study makes clear, however, that an increase in arms can counteract the intended creation of a stable and quiet environment; weapons can intensify pre-existing conflicts and contribute to the self-perpetuating nature of civil unrest and ethnic strife. ${ }^{21}$

\subsection{On the endogeneity of ethnic conflict and civil violence}

The use of the VAR (VECM) framework was primarily based on the potential endogeneity of the institutional variables eth and civviol. It is thus worthwhile to cast a look on this possibility in retrospect, using the empirical results of section 5 .

For ethnic conflict, two of the three adjustment coefficients have been excluded from the model. This tallies well with the results of Derin-Güre (2011), who, using VAR technology, found that there is no causal relationship between economic conditions in south-eastern Turkey and separatist terrorism. These findings suggest that separatist violence has truly deep-rooted foundations in ethnic differences, and that using economic policy to temporarily improve the economic conditions of the Turkish Kurds is less desirable than targeting the improvement of relations over a long-run horizon. For civviol, all three adjustment coefficients are deemed to be statistically significant. This suggests that dissatisfaction with the current government is often related to economic issues such as domestic inflation, confirming the endogeneity of civil unrest.

21 Figure 5 in Goesjenova (2013) illustrates the slight increase in minimum and maximum values of arms imports as a percentage of total imports between 1980 and 1996. 
Response to Nonfactorized One S.D. Innovations

Response of LNIMC to ETH

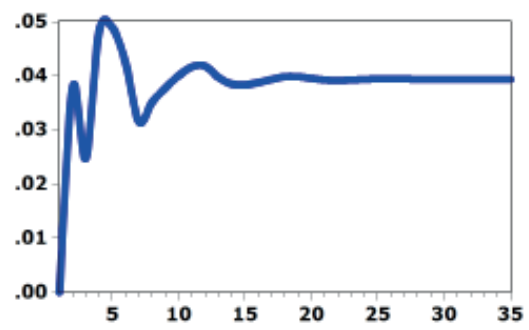

Response of LNRELPRICE to ETH

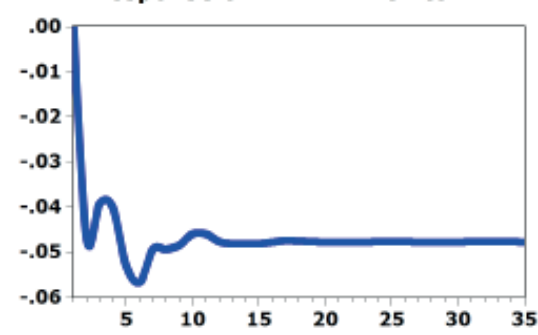

Response of CIVVIOL to ETH

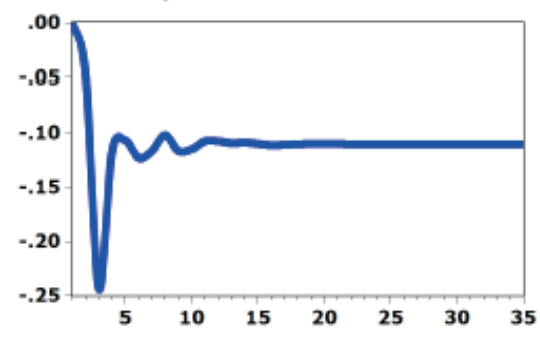

Response of LNGDPC to ETH

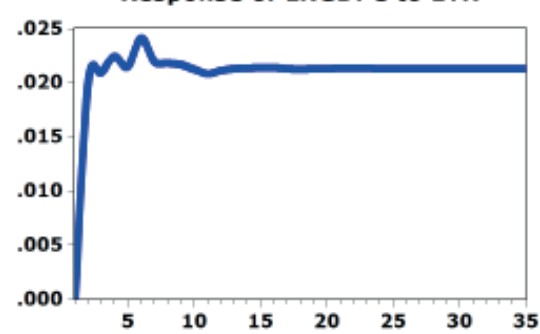

Response of ETH to ETH

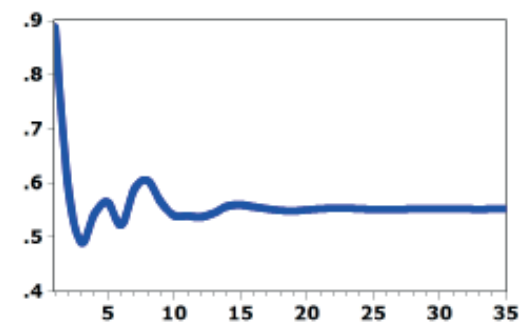

Response of UR to ETH

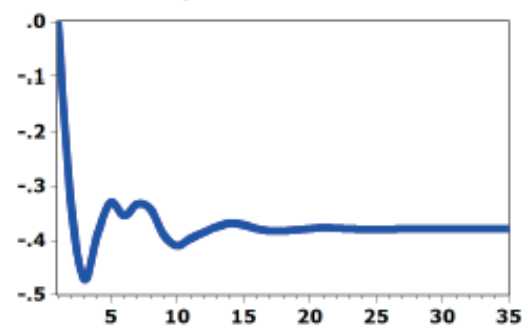

Figure 2: Impulse responses of endogenous variables to a non-factorised one S.D. shock to eth. The horizontal axis displays the number of period after the shock. 
Response to Nonfactorized One S.D. Innovations
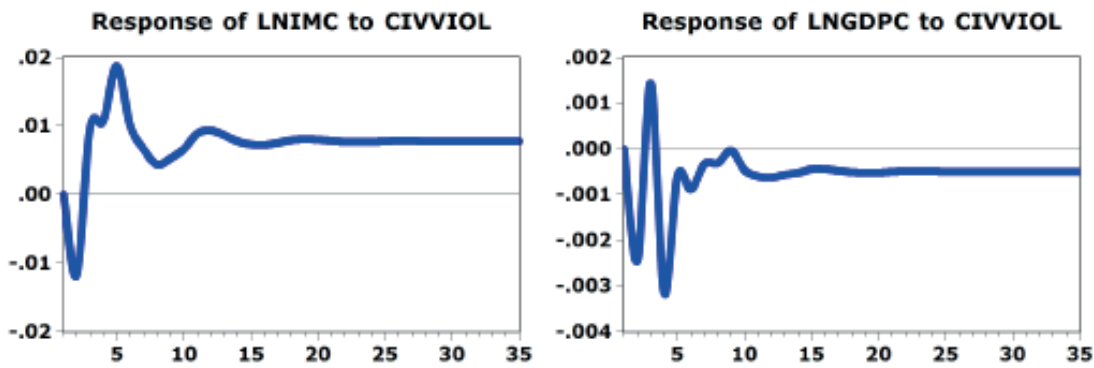

Response of LNRELPRICE to CIVVIOL

Response of ETH to CIVVIOL
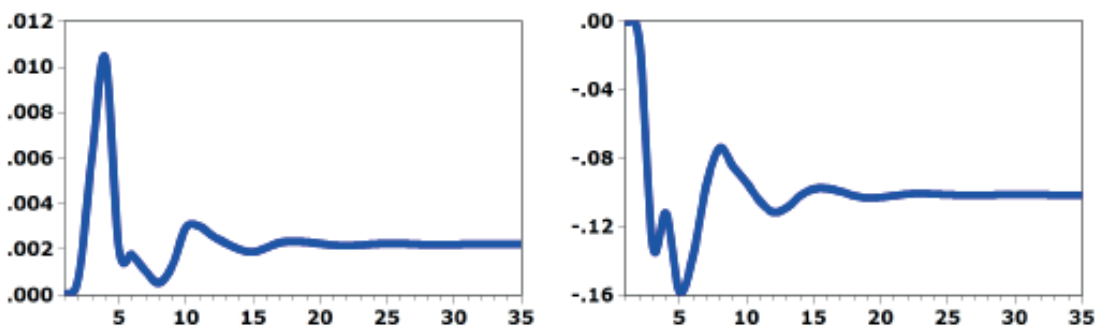

Response of CIVVIOL to CIVVIOL

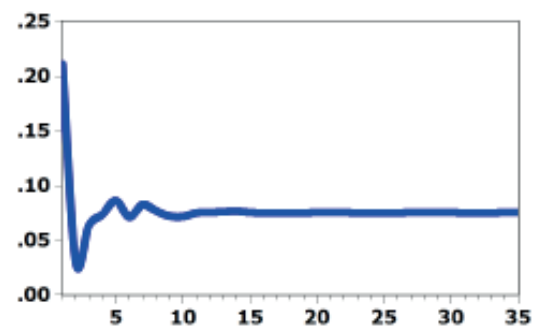

Response of UR to CIVVIOL

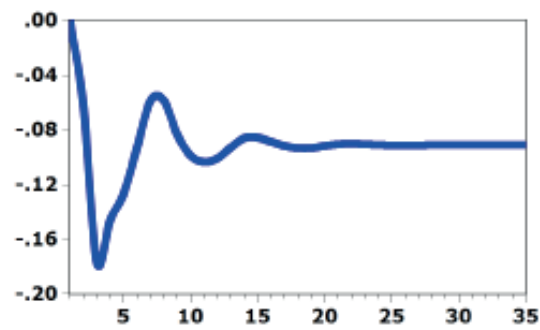

Figure 3: Impulse responses of endogenous variables to a non-factorised one S.D. shock to civviol. The horizontal axis displays the number of period after the shock. 


\section{Concluding remarks}

The motivation for this paper was to examine the effects induced by the recurring episodes of instability and violence Turkey has been experiencing in the second half of the $2 \mathrm{O}^{\text {th }}$ century on Turkish import demand. The resurgence of the Kurdish problem in 2012 and the civil unrest in the first half of 2013 indicates that these problems have been carried on into the 21st century. As Turkey is eye-balling its accession into the Western world, and, in particular, the EU, the Kurdish conflict is continuously put forward as an impediment to Turkey's acceptance into these political and economic realms. The main thrust of this study was that, besides the aforementioned effect, the Turkish economy could also be harmed in the long run by a reduction in the ability to import capital goods, which are essential for technological progress, and thus economic growth.

The possible endogeneity of the political instability and ethnic conflict variables created a preference for the implementation of the vector error correction model. The resulting three long-run relationships indicated effects of the institutional variables on income and imports that were contradicting effects found by existing literature. Civil violence, that is, political instability, and ethnic conflict were both estimated to have a positive effect on GDP per capita and import demand per capita. Besides the usual intricacy involved in interpreting the coefficients of a vector error correction model, which assumes all variables to be endogenous unless specified otherwise, the particular relationship between the civil violence variable and the ethnic conflict variable implied additional difficulties by rendering the ceteris paribus assumption invalid in the case of the ethnic conflict coefficient in the co-integrating equations. A simple regression showed that an increase in ethnic conflict is associated with a decrease of civil violence. These relationships point towards a priority of the ethnic conflict in the minds of the Turks. As the civil violence more often than not involved Turkish intra-ethnic disputes, a reduction in civil violence is thus an implied consequence of growth in ethnic unrest. Impulse response analysis was employed to gain a better insight into the working of the model, and substantiated the earlier finding of a relationship between political and ethnic conflict. The crowding out of civil unrest after an innovation in ethnic instability proved to have a positive effect on the economy and imports due to the localisation of ethnic violence in the already backward south-eastern regions of Turkey and the concentration of civil unrest in the western parts, close to the governing organs; the urban epicentres of economic activity consequently resume their activities after the return of relative peace and quiet. The reason for the disputes surrounding the successes of the liberalisation of the economy after the instalment of the military regime in 1980 is shown to be the 
chosen time period of observation. A shock to civil unrest illustrates that, in the short run, growth can be both positive and negative, but eventually, these effects flatten out and the long-run influence on the economy is negligible. As Aricanli and Rodrik (1990) argue, several things went amiss which prevented Turkey from attaining the possible scenario in which the public sector would have shrunk and the private sector would have achieved remarkable growth. Examples include the creation of a rent-seeking environment and real exchange rate depreciations which hampered the ability of the government to undertake external debt service.

Thus, this study argues, the nature of, and relationship between, civil violence and ethnic conflict in Turkey is pivotal in describing the influence of different macroeconomic variables on the rest of the economy. The VECM framework employed presented another intriguing result which is a characteristic embedded in Turkish ethnic history: there is evidence that ethnic conflict is not significantly endogenous to the economic environment. This does not only put forward a methodological suggestion for future research, but it also indicates possible policy implications. If the Kurdish problem is indeed the first item on the list that inhibits full-edged Turkish acceptance in the economies and politics of the West, the way to achieve ameliorated relationships between the two ethnicities is mostly through political negotiations, probably via international mediation as the ethnic strife has centuries-old roots.

The present analysis advanced the existing economic literature that incorporates institutional variables into the analysis in two distinct ways. First, internal instability has been the focus, in contrast to previous articles which have primarily endeavoured to explain changes to macroeconomic variables due to international conflict. Nevertheless, international conflict is far less common than internal conflict in developing countries. Second, the analysis took into account the endogeneity problem by using the VECM framework. Future research in this area should be directed towards a more advanced model which would include export demand effects, as well as dyadic international relationship effect for a complete analysis of both internal and external conflict consequences on trade. 


\section{References}

Akyuz, K., \& Armstrong, T. (2011). Understanding the sociostructural correlates of terrorism in Turkey.International Criminal Justice Review, 21 (2),134-155.doi:10.1177/1057567711407332

Alesina, A., Özler, S., Roubini, N., \& Swagel, P. (1996). Political instability and economic growth. Journal of Economic Growth, 189-211. Araz-Takay, B., Arin, K. P., \& Omay, T. (2009). The endogenous and non-linear relationship between terrorism and economic performance: Turkish evidence. Defence and Peace Economics, 20 (1), 1-10. Retrieved from http://www.tandfonline.com/doi/abs/10.1080/10242690701775509 doi: $10.1080 / 10242690701775509$

Aricanli, T., \& Rodrik, D. (1990). An overview of Turkeyss experience with economic liberalization and structural adjustment. World Development, 18 (10), 1343-1350. Retrieved from http://www.sciencedirect.com/science/article/pii/0305750X9090114D doi: 10.1016/0305-750X(90)90114-D

Aydin, M. F., Ciplak, U., \& Yücel, M. E. (2004). Export supply and import demand models for the Turkish economy.

Barro, R.J., \& Lee,J.-W.(1994). Sources of economic growth.Carnegie-Rochester Conference Series on Public Policy, 40 (o), 1-46. Retrieved from http://www.sciencedirect.com/science/ article/pii/0167223194900027 doi: http://dx.doi.org/10.1016/0167-2231(94)90002-7

Blanton, S. L. (1999). Instruments of security or tools of repression? Arms imports and human rights conditions in developing countries. Journal of Peace Research, 36 (2), 233-244. Retrieved from http://jpr.sagepub.com/content/36/2/233.abstract doi: $10.1177 / 0022343399036002006$

Blomberg, S. B., \& Hess, G. D. (2006). How much does violence tax trade? The Review of Economics and Statistics, 88 (4), 599-612. Retrieved from http://www.jstor.org/stable/40043022

Caselli, F., Esquivel, G., \& Lefort, F. (1996). Reopening the convergence debate: a new look at crosscountry growth empirics. Journal of Economic Growth, 1 (3), 363\{389. Commission, E. (2013, May). Turkey. EU bilateral trade and trade with the world.

Csaki, C., \& Lerman, Z. (2001). The challenge of rural development in the EU accession countries: Third World Bank/FAO EU accession workshop, Sofia, Bulgaria, June 17-10, 2000 (Vol. 504). World Bank Publications.

Deaton, A., \& Miller, R. I. (1995). International commodity prices, macroeconomic performance, and politics in Sub-Saharan Africa. International Finance Section, Department of Economics, Princeton University. 
Derin-Güre, P. (2011). Separatist terrorism and the economic conditions in south-eastern Turkey. Defence and Peace Economics, 22 (4),393-407. Retrieved from http://www.tandfonline. com/doi/abs/10.1080/10242694.2010.491727 doi: 10.1080/10242694.2010.491727

Eckstein, Z., \& Tsiddon, D. (2004). Macroeconomic consequences of terror: theory and the case of Israel. Journal of Monetary Economics, 51 (5), 971-1002. Retrieved from http:// www.sciencedirect.com/science/article/pii/S0304393204000546 doi: http://dx.doi. org/10.1016/j.jmoneco.2004.05.001

Enders, W. (2008). Applied econometric time series. John Wiley \& Sons.

Ergil, D. (2000). The Kurdish question in Turkey. Journal of Democracy, 11 (3), 122-135.

Houthakker, H. S., \& Magee, S. P. (1969). Income and price elasticities in world trade. The Review of Economics and Statistics, 51 (2), 111-125. Levinsohn, J. (1993). Testing the importsas-market-discipline hypothesis. Journal of International Economics, 35 (1^a2), 1-22. Retrieved from http://www.sciencedirect.com/science/article/pii/o02219969390002F doi: 10.1016/0022-1996(93)90002-F

MacKinnon, J. G. (1996). Numerical distribution functions for unit root and cointegration tests. Journal of Applied Econometrics, 11 (6), 601-618. Retrieved from http://dx.doi. org/10.1002/(SICI)1099-1255(199611)11: 6<601::AID-JAE417>3.0.CO;2-T doi: 10.1002/ (SICI)1099-1255(199611)11:6h601::AID-JAE417i3.0.CO;2-T

MacKinnon, J. G., Haug, A. A., \& Michelis, L. (1999). Numerical distributions of likelihood ratio tests of cointegration. Journal of Applied Econometrics, 14 (563), 577 .

Marshall, M. G. (2012). Major episodes of political violence codebook.

Neyapti, B., Taskin, F., \& Üngör, M. (2007). Has European Customs Union Agreement really affected Turkey's trade? Applied Economics, 39 (16), 2121\{2132.

Nitsch, V., \& Schumacher, D. (2004). Terrorism and international trade: an empirical investigation. European Journal of Political Economy, 20 (2), 423-433. Retrieved from http://www.sciencedirect.com/science/article/pii/S017626800300106X doi: http://dx.doi.org/10.1016/j.ejpoleco.2003.12.009

Rodoplu,U.,Arnold,J., \& Ersoy, G. (2003,5).Terrorism in Turkey. Prehospital and Disaster Medicine, 18,152-160. Retrieved from http://journals.cambridge.org/articleS1049023Xooooog23 doi: 10.1017/S1049023Xooooog23

Srivastava, R. K., \& Green, R. T. (1986). Determinants of bilateral trade ows. The Journal of Business, 59 (4), pp. 623-640. Retrieved from http://www.jstor.org/stable/2353012

Tinbergen, J. (1963). Shaping the world economy. The International Executive, 5 (1), 27-30. Retrieved from http://dx.doi.org/10.1002/tie.5060050113 doi: 10.1002/tie.5060050113

Togan, S., \& Hakan, B. (2007). The Turkish current account, real exchange rate and sustainability: a methodological framework. Journal of International Trade and Diplomacy, 1 (1), 155-192. 